\title{
Penerapan Model Pembelajaran Quantum Teaching untuk Meningkatkan Keaktifan dan Hasil Belajar Siswa Kelas IV SD
}

\author{
Dyah Wahyuning Astrini*, Khusnul Khotimah, Puri Selfi Cholifah \\ Universitas Negeri Malang, Jl. Semarang No. 5 Malang, Jawa Timur, Indonesia \\ *Penulis korespondensi, Surel: dyah.wahyuning.1701516@students.um.ac.id
}

Paper received: 6-8-2021; revised: 20-8-2021; accepted: 28-8-2021

\begin{abstract}
This research aims to describe implementation of the Quantum Teaching learning model to increase student activity and learning outcomes of $4^{\text {th }}$ grade students at Sentul II State Elementary School Purwodadi Pasuruan. The research subjects are 4th grade students at Sentul II State Elementary School. This research uses classroom action research conducted in two cycles. The results of the research showed an increase in student activity which was seen from visual activities, oral activities, writing activities, emotional activities, motor activities, and mental activities. The learning outcomes of $4^{\text {th }}$ grade students which was seen from students' classical learning completeness in the first cycle is 55 percent increasing to 80 percent in the second cycle. The average grade increased from 61 to 73. So, it can be concluded that the application of the Quantum Teaching learning model can increase student activity and learning outcomes of $4^{\text {th }}$ grade students at Sentul II State Elementary School Purwodadi Pasuruan.
\end{abstract}

Keywords: quantum teaching; student activity; learning outcomes

\begin{abstract}
Abstrak
Penelitian ini bertujuan untuk mendeskripsikan pelaksanaan model pembelajaran Quantum Teaching untuk meningkatkan keaktifan siswa dan hasil belajar siswa kelas IV SD Negeri Sentul II Purwodadi Pasuruan. Subjek penelitian yang digunakan adalah siswa kelas IV SDN Sentul II yang berjumlah 20 orang. Penelitian ini menggunakan penelitian tindakan kelas yang dilakukan dalam dua siklus dengan rincian setiap siklus terdiri dari dua pertemuan. Hasil penelitian menunjukkan adanya peningkatan keaktifan siswa dari siklus I ke siklus II yang dilihat dari visual activities, oral activities, writing activities, emotional activities, motoric activities, dan mental activities. Hasil belajar siswa kelas IV juga mengalami peningkatan dilihat dari ketuntasan belajar klasikal siswa pada siklus I sebesar 55 persen meningkat menjadi 80 persen pada siklus II. Rata-rata nilai di kelas tersebut juga mengalami peningkatan dari 61 menjadi 73. Sehingga, dapat disimpulkan bahwa penerapan model pembelajaran Quantum Teaching dapat meningkatkan keaktifan siswa dan hasil belajar siswa kela 4 SDN Sentul II Purwodadi Pasuruan.
\end{abstract}

Kata kunci: quantum teaching; keaktifan siswa; hasil belajar

\section{Pendahuluan}

Pendidikan di sekolah dasar menjadi sumber pendidikan bagi anak setelah dididik oleh orang tua di rumah. Hal ini sesuai dengan pendapat Nurfirdaus dan Hodijah (2018) yang menyatakan bahwa sekolah dasar merupakan tempat bagi siswa dan sumber pendidikan dasar bagi anak untuk mendapatkan ilmu setelah dididik oleh orang tua di rumah. Pendidikan di sekolah dasar memberikan bekal kepada siswa untuk menghadapi perkembangan globalisasi dan menyeimbangkan tuntutan era yang terus berkembang sesuai dengan perubahan zaman.

Di Indonesia, pemerintah menerapkan pembelajaran sekolah dasar dengan kurikulum 2013 yang berbasis tematik. Menurut Sugiyarti dkk (2018) menyatakan bahwa di era kurikulum 2013 terdapat 4 kompetensi penting yang harus dimiliki siswa antara lain 
Creativity, Communication, Critical Thinking dan Collaboration. Untuk menerapkan pembelajaran dengan memperhatikan keempat kompetensi siswa tersebut, guru sebagai pengajar harus menciptakan kondisi belajar yang ideal dengan memanfaatkan berbagai sumber belajar. Sehingga, pemahaman konsep materi yang diberikan kepada siswa menjadi lebih mudah.

Pembelajaran di SD harus mampu menciptakan interaksi dari berbagai komponen pembelajaran agar bisa mengembangkan segala potensi dan kecakapan yang ada pada siswa. Adapun prinsip-prinsip dari pembelajaran di SD menurut Ali (2013) antara lain keaktifan, keterlibatan langsung, tantangan, pengulangan, perhatian, motivasi, dan perbedaan individu. Melalui penerapan prinsip pembelajaran di SD, pembelajaran yang dilakukan oleh guru menjadi lebih optimal dan mampu mengaitkan segala hal yang ada di kehidupan nyata. Prinsipprinsip pembelajaran di SD dapat diterapkan dengan mengaplikasikan berbagai macam strategi, metode, media, dan model pembelajaran yang sesuai dengan karakteristik siswa SD.

Guru perlu mengaplikasikan model pembelajaran yang disesuaikan pula dengan kebutuhan belajar, karakteristik siswa dan pembelajaran yang ideal. Pembelajaran yang ideal merupakan pembelajaran yang mampu melibatkan siswa dalam beraktivitas di dalam kelas. Hal ini sesuai dengan pernyataan dari Setyosari (2014) yang menyatakan bahwa pembelajaran ideal adalah pembelajaran yang mampu membuat siswa aktif, mencapai tujuan pembelajaran secara efektif, dapat mendorong kreativitas siswa, pembelajaran berpusat pada siswa dan kegiatan berlangsung dalam suasana yang menyenangkan. Oleh karena itu, penting bagi guru untuk menciptakan suasana pembelajaran yang lebih bermakna dan menambah keterlibatan siswa.

Penyajian pembelajaran diharapkan dapat memenuhi prinsip pembelajaran yang ideal. Namun faktanya, penyajian pembelajaran di lapangan berbeda. Seperti yang dialami di kelas IV SDN Sentul II. Berdasarkan hasil observasi pembelajaran luring di kelas IV pada hari Rabu tanggal 20 Januari 2021, menunjukkan bahwa penyajian pembelajaran masih berfokus pada guru dan sumber belajar yang disediakan sekolah. Kegiatan pembelajaran dilakukan dengan pemberian tugas terus menerus sehingga siswa terlihat bosan dalam mengikuti proses pembelajaran. Kurangnya variasi model yang disediakan oleh guru, siswa menjadi kurang terlibat dalam proses belajar mengajar. Pembelajaran seperti ini dirasa kurang efektif dikarenakan kurangnya kegiatan yang mampu mendorong siswa untuk aktif.

Permasalahan terkait keaktifan siswa diperkuat dengan hasil wawancara bersama Ibu MCS pada tanggal 20 Januari 2021 selaku guru kelas IV bahwa siswa di kelas IV yang aktif saat mengikuti pembelajaran menjadi golongan minoritas, sedangkan siswa yang kurang aktif di kelas IV menjadi golongan mayoritas. Beliau mengungkapkan bahwa siswa enggan untuk terlibat dalam proses pembelajaran yang dilakukan. Beliau juga mengungkapkan bahwa selama beliau mengajar di kelas IV SDN Sentul II ini, beliau merasa berhasil memberikan pembelajaran hanya dengan siswa yang itu-itu saja, sedangkan yang lain hanya menjadi partisipan di dalam kelas. Hasil belajar siswa juga masih rendah. Hal ini dibuktikan melalui studi dokumentasi data nilai siswa kelas IV SDN Sentul II. Siswa yang mampu mencapai nilai KKM hanya berjumlah 8 siswa saja, sedangkan 12 siswa lainnya masih belum mampu mencapai KKM. Ketuntasan hasil belajar klasikal hanya mampu mencapai $40 \%$, sedangkan siswa yang mendapat nilai di bawah KKM sebesar 60\%. Begitu pula dengan rata-rata nilai yaitu 56 masih rendah. 
Berdasarkan permasalahan yang muncul, maka alternatif cara yang dijadikan solusi oleh peneliti adalah menerapkan model pembelajaran Quantum Teaching di kelas IV. De Porter dkk (2013) menyatakan bahwa model ini mampu membuat proses belajar dengan menyertakan segala interaksi, kaitan dan perbedaan yang terjadi di kelas. Fokus dari model pembelajaran ini adalah adanya hubungan dinamis antara guru dan siswa dengan memanfaatkan dan memaksimalkan seluruh aktivitas, potensi, sarana-prasarana dan interaksi yang muncul. Ditinjau dari prinsip utama pembelajaran Quantum Teaching, pembelajaran Quantum Teaching mampu menciptakan interaksi antar komponen pembelajaran di kelas. Apalagi dengan tahapan-tahapan pada model ini yang terdiri dari Tumbuhkan, Alami, Namai, Demonstrasikan, Ulangi dan Rayakan (TANDUR) bisa membantu siswa dalam mengembangkan potensinya dengan bertahap. Model ini juga menggunakan variasi kegiatan yang menyenangkan dan bermakna bagi siswa.

Keberhasilan penerapan model Quantum Teaching di SD pada pembelajaran tematik dinilai sangat efektif dilakukan. Hal ini sesuai dengan penelitian yang telah dilakukan oleh Sri Susanti dan Yalvema Miaz (2020) yang berjudul "Peningkatan Hasil Belajar Siswa pada Tematik Terpadu dengan Menggunakan Model Quantum Teaching di Sekolah Dasar". Hasil dari penelitian tersebut menyimpulkan bahwa terdapat peningkatan yang signifikan dalam hasil penilaian pembelajaran tematik terpadu menggunakan model pembelajaran Quantum Teaching pada siswa kelas V SD Negeri 03 Pasaman. Berdasarkan penelitian tersebut disebutkan pula bahwa model Quantum Teaching ini mampu membuat siswa lebih antusias dan berinteraksi dengan keadaan kelas.

Berdasarkan paparan permasalahan dan solusi pemecahan masalah yang diusulkan, hipotesis penelitian ini adalah apabila model pembelajaran Quantum Teaching diterapkan di kelas IV SDN Sentul II, maka keaktifan siswa dan hasil belajar siswa meningkat. Peneliti tertarik untuk melakukan penelitian tindakan kelas yang bertujuan untuk mendeskripsikan penerapan proses pembelajaran dengan menggunakan model pembelajaran Quantum Teaching dan mengetahui peningkatan dari keaktifan dan hasil belajar siswa kelas IV SDN Sentul II Purwodadi Pasuruan setelah diberi tindakan model Quantum Teaching.

\section{Metode}

Metode penelitian yang digunakan adalah penelitian tindakan kelas atau Classroom Action Research. Berdasarkan latar belakang yang dipaparkan oleh peneliti, peneliti bertujuan untuk meningkatkan keaktifan dan hasil belajar siswa dengan memanfaatkan suatu model pembelajaran yaitu model Quantum Teaching. Hal ini sesuai dengan tujuan dari PTK menurut Mulia dan Suwarno (2016) yaitu untuk memperbaiki dan meningkatkan kualitas pembelajaran di kelas secara terus menerus. Pada penelitian tindakan kelas ini, peneliti menggunakan pendekatan kualitatif interaktif. Peneliti akan melakukan studi mendalam dengan teknik pengumpulan data secara langsung dari sumber data dalam lingkungan yang diteliti. Penelitian dengan pendekatan ini dapat membantu peneliti membuat gambaran menyeluruh dengan deskripsi yang detail terkait penerapan tindakan yang dilakukan di kelas.

Penelitian tindakan kelas di kelas IV SDN Sentul II dilaksanakan dalam 2 siklus. Siklus I merupakan pelaksanaan awal tindakan dilakukan setelah perencanaan. Sedangkan siklus II menjadi proses tindak lanjut dari hasil penelitian pada siklus I. Setiap siklus dilaksanakan selama 2 kali pertemuan yang masing-masing pertemuan 2 jam pelajaran. Setiap 1 jam pelajaran di SD dilaksanakan selama 35 menit. Sehingga dalam 1 kali pertemuan dalam setiap 
siklus dilaksanakan selama kurang lebih 70 menit. Pada pertemuan 1 dilakukan kegiatan pembelajaran seperti biasa begitu juga dengan pertemuan 2 . Di pertemuan 2 , kegiatan diakhiri dengan tes evaluasi formatif.

Setiap siklus dilakukan dengan tahapan-tahapan sesuai bagan penelitian tindakan kelas. Kegiatan penelitian meliputi empat tahapan diantaranya perencanaan (Plan), pelaksanaan (Act), observasi (Observation), dan refleksi (Reflection). Tahapan ini mengacu pada pedoman model PTK yang dikembangkan oleh Kemmis \& McTaggart (2014). Tahap perencanaan terdiri dari merancang RPP, merancang media pembelajaran dan lembar kegiatan siswa, menyusun instrumen penelitian dan menyusun tes evaluasi formatif. Pada tahapan pelaksanaan, peneliti mengimplementasikan isi rancangan pembelajaran berbasis model pembelajaran Quantum Teaching. Tahap observasi dilakukan dengan mengamati proses tindakan model pembelajaran Quantum Teaching. Tahap refleksi merupakan kegiatan dimana peneliti berpikir ulang dan menganalisis implementasi tindakan pembelajaran dengan menerapkan model pembelajaran Quantum Teaching di kelas.

Jenis data yang digunakan pada penelitian tindakan kelas ini terdiri dari data kuantitatif dan data kualitatif. Data kuantitatif didapatkan dari data nilai evaluasi formatif siswa. Sedangkan data kualitatif didapatkan dari data proses keterlaksanaan model Quantum Teaching dan aktivitas siswa selama proses belajar mengajar berlangsung. Sumber data pada penelitian ini yaitu siswa kelas IV SD Negeri Sentul II, guru kelas IV SD Negeri Sentul II dan dokumentasi perangkat pembelajaran yang relevan.

Lokasi penelitian dilakukan di kelas IV SDN Sentul II yang terletak di Jl. Arjuno No. 02 Dusun Gunting Desa Sentul Kecamatan Purwodadi Kabupaten Pasuruan Provinsi Jawa Timur. Subjek penelitian dalam penelitian ini dilakukan adalah siswa kelas IV SDN Sentul II pada semester genap tahun pelajaran 2020/2021 yang memiliki 20 orang siswa yang terdiri dari 9 orang siswa perempuan dan 11 orang siswa laki-laki. Waktu pelaksanaan penelitian di SDN Sentul II dilakukan pada bulan Maret-April 2020/2021.

Teknik pengumpulan data meliputi observasi, wawancara, dokumentasi dan tes. Teknik analisis data penelitian ini menggunakan analisis data kualitatif. Adapun proses analisis data kualitatif ini mengacu pada analisis data kualitatif menurut Akbar (2013) yang meliputi pemaparan fakta-fakta, reduksi data, kategorisasi dan interpretasi. Kemudian penarikan kesimpulan didasarkan pada proses keterlaksanaan model pembelajaran Quantum Teaching..

\section{Hasil dan Pembahasan}

Penelitian dimulai dengan studi pendahuluan kegiatan belajar mengajar di kelas IV SDN Sentul II pada hari Rabu tanggal 20 Januari 2021. Berdasarkan studi pendahuluan tersebut, menunjukkan bahwa variasi model pembelajaran yang diterapkan masih kurang. Pembelajaran yang masih berpusat pada guru dan pemberian tugas yang berkelanjutan dapat menciptakan kejenuhan bagi siswa. Apalagi sumber belajar yang memfasilitasi siswa untuk belajar terbatas. Sehingga keterlibatan siswa dalam proses belajar mengajar juga kurang. Keaktifan siswa di kelas IV SDN Sentul masih kurang. Siswa yang kurang aktif masih mendominasi. Pembelajaran yang kurang menarik dapat menjadikan siswa kurang antusias. Kurangnya kegiatan yang mampu mendorong siswa untuk aktif dapat menjadi permasalahan keaktifan siswa muncul. Terkait dengan hasil belajar siswa sebelum tindakan menunjukkan hasil yang masih rendah. Siswa yang mampu mencapai nilai KKM adalah 8 siswa, sedangkan 
12 siswa lainnya belum tuntas hasil belajarnya. Rata-rata di kelas IV tergolong rendah yaitu 56. Persentase ketuntasan secara klasikal di kelas tersebut sebesar $40 \%$.

Setelah menganalisis permasalahan dan solusi yang digunakan berupa penerapan model Quantum Teaching, peneliti bersama guru kolaborator melaksanakan tindakan siklus I. Muatan yang dibahas adalah Bahasa Indonesia, IPS, dan PPKn. Materi yang diberikan berdasarkan tema 7 (Indahnya Keragaman di Negeriku) subtema 1 (Keragaman Suku Bangsa dan Agama di Negeriku) pembelajaran 3 dan 4. Siklus I dilaksanakan pada 29-30 Maret 2021 dengan rincian pertemuan pertama pada 29 Maret 2021 dan pertemuan kedua pada 30 Maret 2021.

Berdasarkan data hasil observasi siklus I pertemuan 1 dan pertemuan 2, diperoleh temuan penelitian antara lain: (1) peneliti dalam melaksanakan pembelajaran menggunakan model Quantum Teaching dengan langkah TANDUR masih belum terlaksana dengan optimal. Ada tahapan-tahapan yang belum dilaksanakan dengan baik, (2) interaksi antara peneliti dan siswa kurang luwes. Sehingga, peneliti kurang optimal dalam mengajak siswa aktif. Banyak siswa yang masih menunjukkan sikap takut salah dan malu menjawab, (3) pada saat tahapan demonstrasi, kegiatan yang dilakukan belum terkondisikan dengan baik, (4) menumbuhkan minat siswa melalui stimulus pertanyaan saja masih kurang memberikan dampak terhadap ketertarikan siswa terhadap materi, (5) tahapan ulangi dan rayakan berlangsung dengan optimal dalam siklus I. Pemberian reward dan pengakuan terhadap kerja keras siswa membuat siswa senang dan lebih semangat dalam belajar. Namun, ada beberapa siswa yang masih belum mampu mengingat materi dengan baik, (6) sesuai dengan hasil observasi, keaktifan siswa di kelas IV pada saat pembelajaran masih kurang. Masih ada beberapa siswa yang kurang memperhatikan temannya saat presentasi. Banyak siswa yang ramai sendiri saat kegiatan membaca. Aspek keaktifan siswa masih belum muncul secara keseluruhan dengan optimal, dan (7) hasil belajar siswa pada siklus I menunjukkan hasil yang lebih baik, tetapi ketuntasan siswa masih belum memenuhi kriteria keberhasilan dan rata-rata masih setara dengan KKM sekolah.

Berdasarkan hasil refleksi pada penerapan model pembelajaran Quantum Teaching, pelaksanaan tindakan berjalan dengan lancar dan kronologis, tetapi belum mencapai hasil yang sempurna karena masih ada hambatan terkait keaktifan siswa, hasil belajar dan proses pelaksanaannya. Oleh karena itu, tindakan Quantum Teaching ini masih perlu perbaikan proses pembelajaran melalui pelaksanaan tindakan siklus II.

Bertolak dari refleksi tindakan siklus I, maka peneliti dan guru kolaborator mengadakan perbaikan terhadap kegiatan pembelajaran sebagai rencana terevisi. Muatan yang dibahas masih sama yaitu adalah Bahasa Indonesia, IPS, dan PPKn. Materi yang diberikan berdasarkan tema 7 (Indahnya Keragaman di Negeriku) subtema 2 (Indahnya Keragaman Budaya Negeriku) pembelajaran 3 dan 4. Siklus II dilaksanakan pada 05-06 April 2021 dengan rincian pertemuan pertama pada 05 April 2021 dan pertemuan kedua pada 062021.

Setelah pelaksanaan tindakan siklus II dilakukan, peneliti dan guru kolaborator melakukan refleksi. Adapun hasil refleksi siklus II antara lain: (1) proses pembelajaran yang telah dirancang guru bertolak dari hasil yang dicapai telah berjalan dengan lancar dan memenuhi target yang diharapkan. (2) keterlaksanaan model Quantum Teaching lebih terorganisir dengan baik. Stimulus-stimulus yang beragam seperti pertanyaan dan media dapat memberikan motivasi kepada siswa dalam mengembangkan minat belajarnya, (3) keaktifan siswa dalam siklus II mengalami peningkatan dari siklus I. Melalui pendekatan dan interaksi bersama siswa memungkinkan siswa terlibat dalam segala aktivitas belajar. Aktivitas 
siswa yang terdiri dari visual activities, oral activities, writing activities, emotional activities, motorik activities, dan mental activities muncul dalam setiap kegiatan pembelajaran sesuai indikator, dan (4) hasil belajar siswa kelas IV yang dicapai menunjukkan hasil yang signifikan. Hal ini ditunjukkan dari peningkatan yang diperoleh siswa setelah tindakan model Quantum Teaching yaitu pada siklus I diperoleh nilai rata-rata 61 dengan persentase ketuntasan sebesar $55 \%$. Sedangkan pada siklus II diperoleh nilai rata-rata 73 dengan peningkatan persentase ketuntasan mencapai $80 \%$.

Perbaikan yang diterapkan di siklus II menunjukkan hasil bahwa keterlaksanaan proses pembelajaran dengan model Quantum Teaching sudah diterapkan secara berurutan dan sesuai dengan prosedur. Keaktifan siswa juga mengalami peningkatan. Hal ini ditunjukkan dari lebih banyak siswa yang melaksanakan aktivitas-aktivitas belajar. Contohnya ketika siswa diberikan kesempatan mendemonstrasikan pengetahuannya melalui puzzle, siswa terlihat antusias menyelesaikan dengan cepat. Potret kegiatan demonstrasi pada siklus II ditunjukkan pada Gambar 1. Bertolak dari paparan hasil refleksi siklus II ini, peneliti berpendapat bahwa tidak perlu dilakukan tindakan berikutnya dan penelitian ini dinyatakan selesai.

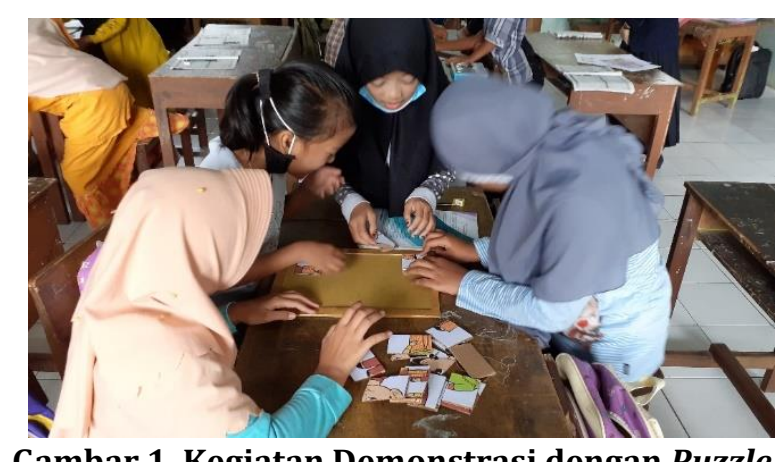

Gambar 1. Kegiatan Demonstrasi dengan Puzzle

Hasil belajar siswa kelas IV SDN Sentul II menunjukkan hasil yang maksimal. Mulai dari pra tindakan hingga siklus II dilaksanakan hasil belajar siswa mengalami peningkatan. Peningkatan data hasil belajar siswa kelas IV disajikan dalam tabel 1.

Tabel 1. Perbandingan Hasil Belajar Siswa Kelas IV SDN Sentul II

\begin{tabular}{llccc}
\hline No & Kriteria & Pra Tindakan & Siklus I & Siklus II \\
\hline 1 & Jumlah Siswa Tuntas & 8 & 11 & 16 \\
2 & Jumlah Siswa Belum Tuntas & 12 & 9 & 4 \\
3 & Rata-Rata & 56 & 61 & 73 \\
4 & Presentase Ketuntasan Klasikal & $40 \%$ & $55 \%$ & $80 \%$ \\
5 & Presentase Ketidaktuntasan Klasikal & $60 \%$ & $45 \%$ & $20 \%$ \\
\hline
\end{tabular}

Berdasarkan tabel 1 di atas, menunjukkan bahwa hasil belajar siswa mengalami peningkatan dari pra tindakan ke siklus I dan siklus II. Peningkatan ini dilihat dari pra tindakan ke siklus I jumlah siswa yang mampu mencapai ketuntasan belajar meningkat menjadi 11 siswa. Kemudian di siklus II, jumlah siswa yang tuntas semakin bertambah menjadi 16 siswa. Seiring dengan meningkatnya jumlah siswa yang mampu mencapai ketuntasan belajar, jumlah 
siswa yang belum tuntas mengalami penurunan hingga tersisa 4 siswa saja. Meningkatnya hasil belajar siswa di kelas IV ini juga ditunjukkan dengan nilai rata-rata. Rata-rata pra tindakan sebesar 56 meningkat menjadi 61 pada siklus I. Rata-rata tersebut kembali meningkat menjadi 73. Persentase ketuntasan klasikal pada pra tindakan yang mencapai $40 \%$ meningkat menjadi 55\%. Presentase ini lebih meningkat setelah dilakukan siklus II yaitu sebesar $80 \%$.

Model Quantum Teaching yang diterapkan di kelas IV SDN Sentul II berjalan sesuai dengan prosedur dan berurutan. Langkah tumbuhkan yang dilakukan dengan stimulus pertanyaan dan media yang menarik seperti miniatur rumah adat dan peta Indonesia membuat siswa lebih tertarik dan tumbuh rasa ingin tahunya. Minat siswa dapat berkembang apabila siswa diikutsertakan dalam proses belajar seperti dalam interaksi dalam kegiatan tanya jawab dan bereksplorasi bersama dengan memanfaatkan media yang ada. Hal ini sesuai dengan pendapat Tambunan (2018) yang menyatakan bahwa dalam model Quantum Teaching pada tahap tumbuhkan guru harus berusaha mengikutsertakan siswa dalam proses belajar. Pemberian apersepsi, interaksi, motivasi, eksplorasi dan stimulus yang tepat dapat membuat siswa tertarik untuk mengikuti rangkaian kegiatan pembelajaran. Menggali manfaat mempelajari materi yang dilakukan oleh guru dan siswa juga menjadi cara dalam menumbuhkan minat belajar siswa. Hal ini sesuai dengan prinsip model Quantum Teaching yang dikemukakan De Porter dkk (2013) yaitu "Apakah Manfaatnya Bagiku" (AMBAK). Guru sebisa mungkin perlu memasuki alam pikiran siswa dan menanamkan bahwa apa yang dipelajari memberikan manfaat yang besar dalam kehidupannya.

Tahapan alami yang dilakukan dengan menciptakan dan menghubungkan pengalaman siswa dengan materi yang akan dibahas dapat membangkitkan rasa ingin tahu siswa lebih dalam. Kegiatan yang dilakukan seperti mencermati media dan bereksplorasi sesuai dengan prinsip model pembelajaran Quantum Teaching yaitu pengalaman sebelum pemberian nama. Menurut De Porter dkk (2013) menyatakan bahwa sebelum memulai untuk menemukan suatu konsep, siswa perlu diajak untuk memahami materi dari pengalaman langsung. Kegiatan ini dapat membangkitkan otak dan rasa ingin tahu siswa. Hal ini juga sesuai dengan karakteristik siswa SD menurut Bujuri (2018) bahwa siswa masih dalam tahap operasional konkret. Sehingga, siswa memerlukan alat bantu dan pengetahuan awal sebagai cara untuk memahami hal yang masih baru dan abstrak. Contoh potret kegiatan eksplorasi sumber belajar di kelas ditunjukkan pada Gambar 2.

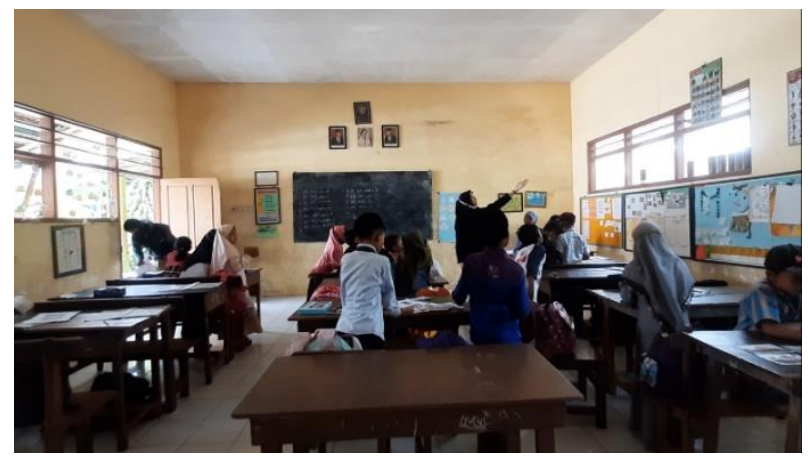

Gambar 2. Eksplorasi mading rumah adat

Pada tahap namai baik siklus I dan siklus II, siswa dibimbing dalam memahami konsep tentang keragaman suku bangsa, bahasa daerah, rumah adat dan pakaian adat daerah di 
Indonesia. Guru menggunakan beberapa kata kunci yang berhubungan materi seperti pada pembahasan ide pokok, kata kunci yang digunakan adalah terdapat pada awal kalimat atau akhir kalimat. Begitu pula dengan materi yang berhubungan dengan muatan IPS dan PPKn seperti keragaman budaya Indonesia. Guru memberikan cara untuk mengingat keunikan dan ciri khas yang membedakan kebudayaan daerah satu dengan yang lainnya. Pemanfaatan media seperti gambar membantu siswa dalam memberikan identitas sesuai dengan materi.

Tahapan namai diwujudkan dengan membimbing siswa dalam menemukan konsep menggunakan kata kunci sederhana dan dibantu sumber belajar. Hal ini sesuai dengan konsep langkah namai yang dikemukakan oleh pencetus model Quantum Teaching De Porter dkk (2013) yang menyatakan bahwa guru perlu menyiapkan kata kunci yang mudah dimengerti siswa, konsep yang jelas dan kegiatan yang dapat dilakukan oleh siswa. Langkah namai juga sudah tepat apabila dilakukan setelah menciptakan pengalaman langsung bagi siswa. Sehingga, pengetahuan awal siswa dapat terkonsep dan berkesan bagi siswa. Sesuai dengan pendapat dari Tambunan (2018) bahwa tahapan penamaan setelah pengalaman akan membuat konsep tersebut lebih bermakna dan berkesan. Melalui penamaan ini juga, siswa akan terpacu kognitifnya untuk memberikan identitas, menguatkan dan memberikan definisi sesuai dengan apa yang diperoleh.

Pada siklus I, tahapan demonstrasikan dilakukan dengan cara menyampaikan hasil diskusi kelompok di depan kelas, permainan menghubungkan gambar suku bangsa dengan asal daerahnya, dan permainan menempel kata-kata bahasa daerah yang sepadan dengan bahasa Indonesia secara berpasangan. Pada siklus II ini, tahapan demonstrasikan diwujudkan dalam kegiatan menyampaikan hasil diskusi kelompok, kompetensi antar kelompok dalam hal mengidentifikasi nama, asal daerah dan keunikan dari beberapa rumah adat, dan guru memanfaatkan puzzle untuk siswa sebagai bentuk permainan yang menyenangkan. Siswa terlihat sangat antusias pada kegiatan demonstrasi dilihat dari ketertarikan siswa dalam menyelesaikan pekerjaannya. Kegiatan yang menyenangkan seperti permainan sederhana dapat membantu siswa untuk lebih antusias. Hal ini sesuai dengan pendapat De Porter dkk (2013) yang menyatakan bahwa pada tahap demonstrasikan guru menyediakan kesempatan bagi siswa untuk memperagakan atau menunjukkan apa yang telah mereka ketahui. Sejalan dengan pendapat Tambunan (2018) yang menyebutkan bahwa tahap demonstrasi dapat dilakukan dengan menyajikan hasil diskusi di depan kelas, permainan dan menunjukkan pekerjaan siswa. Melalui kegiatan ini, siswa akan lebih mudah dalam memahami dan mengingat materi.

Tahapan ulangi pada siklus I dan II dilakukan pada kegiatan akhir sebelum siswa melakukan evaluasi dan menutup pembelajaran. Guru melakukan tahap ulangi dengan cara mengajak siswa merangkum dan menyimpulkan hasil pembelajaran yang telah dilakukan. Setelah membimbing siswa menyimpulkan, guru memberikan beberapa pertanyaan untuk melatih ingatan siswa. Hal ini membuktikan pernyataan dari De Porter dkk (2013) bahwa tahapan ulangi pada model Quantum Teaching dapat memperkuat koneksi saraf siswa sehingga materi belajar dapat bertahan lebih lama dalam ingatan siswa. Tahapan ulangi dapat diwujudkan melalui kegiatan merangkum, memberikan penguatan materi, memberi kesempatan siswa untuk menyimpulkan bersama materi yang telah dipelajari, dan melakukan tanya jawab secara singkat untuk melatih ingatan siswa. 
Tahapan rayakan pada siklus I dan siklus II diwujudkan di setiap kegiatan pembelajaran. Kegiatan seperti tanya jawab, permainan, dan diskusi diakhiri dengan memberikan pujian dan mengapresiasi usaha siswa. Contohnya ketika permainan selesai dilakukan, guru memberikan reward kepada siswa dan kelompok yang mampu menyelesaikan dengan baik. Siswa sangat antusias ketika mendapatkan apresiasi dari guru. Siswa juga terlihat lebih semangat. Berdasarkan paparan data tersebut, menunjukkan bahwa tahap rayakan memberikan dampak untuk memotivasi siswa. Sesuai dengan yang disampaikan oleh De Porter dkk (2013) bahwa melalui kegiatan perayaan dapat menghargai usaha, ketekunan dan kepercayaan diri siswa. Sehingga dapat dikatakan bahwa tahap rayakan pada model Quantum Teaching yang dilakukan dengan cara memberikan pujian dan apresiasi dapat melatih kepercayaan diri dan memotivasi siswa untuk belajar.

Model Quantum Teaching yang diterapkan di kelas IV SDN Sentul II dapat meningkatkan keaktifan siswa. Hal ini dibuktikan dari munculnya indikator-indikator pada aspek keaktifan siswa. Pada aspek visual activities, menunjukkan bahwa siswa terlihat tertib dalam kegiatan membaca. Siswa memperhatikan penjelasan guru dengan baik dilihat dari respon siswa yang dengan cepat menjawab pertanyaan ketika peneliti bertanya dan membimbing siswa. Media pembelajaran berupa gambar dan miniatur yang disediakan membuat siswa lebih tertarik. Pada aspek oral activities, menunjukkan bahwa siswa mulai berani untuk bertanya kepada guru. Hal ini terlihat ketika peneliti berkeliling membimbing siswa diskusi, masing-masing kelompok tidak malu untuk bertanya hal sulit kepada guru. Hampir semua siswa aktif dalam berdiskusi. Pada aspek writing activities, menunjukkan bahwa siswa membuat rangkuman dengan spontan tanpa diminta terlebih dahulu oleh guru. Pada saat kegiatan diskusi, setiap kelompok bekerja sama mengerjakan LKPD dengan baik. Pada aspek emotional activities, menunjukkan bahwa siswa sangat antusias dalam kegiatan bermain salah satunya puzzle. Suasana kelas terlihat lebih kondusif dan siswa tidak berebut untuk menjawab atau berpendapat. Hampir semua siswa sudah mulai berani untuk tampil di depan kelas. Pada aspek motoric activities, menunjukkan bahwa semua siswa cukup aktif dalam melakukan diskusi dan mempresentasikan hasil diskusinya. Siswa lebih terkondisikan dengan baik. Mereka maju ke depan ketika ditunjuk oleh guru. Sehingga, siswa tidak saling berebut untuk mendapat giliran. Pada aspek mental activities, menunjukkan bahwa siswa mampu memecahkan soal dengan baik yang terlihat ketika proses diskusi berlangsung. Hampir semua siswa mampu menghubungkan konsep dengan benar karena peneliti memberikan kata kunci yang lebih sederhana dan berhubungan dengan kehidupan sehari-hari.

Peningkatan keaktifan siswa terjadi karena siswa sudah beradaptasi dengan kegiatan model Quantum Teaching dan intensitas interaksi antara peneliti dan siswa membuat siswa lebih aktif dan tidak malu untuk bertanya maupun menjawab pertanyaan. Langkah demonstrasikan yang dilakukan dengan permainan yang menarik dan menyenangkan juga mendukung siswa untuk lebih aktif dan bersemangat untuk belajar. Hal ini terlihat dari antusiasme siswa dalam mengerjakan permainan menempel dan puzzle selama tindakan model Quantum Teaching tahap demonstrasikan. Siswa lebih tertantang jika mereka mendemonstrasikan pengetahuannya melalui kompetisi. Sesuai dengan pendapat Santrock (2014) menyatakan bahwa siswa lebih termotivasi untuk belajar terlibat dalam tantangan yang sesuai dengan kemampuan dan menerima hadiah. Cara guru memberikan kesempatan pada siswa mendemonstrasikan pengetahuannya dengan kegiatan yang menarik membuat siswa lebih aktif dan bersemangat. 
Model Quantum Teaching yang digunakan dalam pembelajaran di kelas IV SDN Sentul II dapat meningkatkan hasil belajar siswa. Hal ini dibuktikan dari hasil belajar yang diperoleh siswa mengalami peningkatan dari pra tindakan ke siklus I dan siklus II. Jumlah siswa yang mendapatkan nilai di atas rata-rata setelah siklus II adalah 16 siswa. Persentase ketuntasan setelah diberi tindakan siklus II mencapai $80 \%$ dimana presentase ini meningkat tinggi sebesar $25 \%$ dari siklus I. Rata-rata yang didapatkan pada siklus II mencapai 73 lebih tinggi daripada rata-rata siklus I yaitu 61. Adanya kegiatan pembelajaran yang dikemas secara menarik dan menyenangkan dalam model Quantum Teaching dapat meningkatkan hasil belajar siswa. Pembuktian ini sesuai dengan yang dikemukakan oleh Susanti dan Miaz (2020) bahwa melalui model Quantum Teaching dapat membuat siswa menjadi lebih antusias dan membuat proses belajar efektif serta dapat meningkatkan hasil belajar.

\section{Simpulan}

Berdasarkan hasil penelitian dan pembahasan yang telah dipaparkan, maka dapat ditarik beberapa kesimpulan diantaranya pelaksanaan proses pembelajaran dengan menggunakan model pembelajaran Quantum Teaching untuk meningkatkan keaktifan dan hasil belajar siswa kelas IV SDN Sentul II Purwodadi Pasuruan sudah terlaksana sesuai dengan prosedur dan berurutan. Pembelajaran yang dilaksanakan dengan tahapan yang terdiri dari Tumbuhkan, Alami, Namai, Demonstrasikan, Ulangi dan Rayakan (TANDUR) berjalan dengan optimal dan efektif. Sehingga, tercipta suasana belajar yang menyenangkan dan dapat mencapai tujuan pembelajaran yang diharapkan.

Penerapan model pembelajaran Quantum Teaching yang diterapkan di kelas IV SDN Sentul II Purwodadi Pasuruan mampu meningkatkan keaktifan siswa. Proses pembelajaran dengan kegiatan yang bervariasi dan melibatkan siswa dalam setiap kegiatan, membuat siswa lebih aktif dalam proses pembelajaran. Aspek-aspek keaktifan siswa yang terdiri dari visual activities, oral activities, writing activities, mental activities, emotional activities, dan motor activities dapat terpenuhi secara optimal.

Penerapan model pembelajaran Quantum Teaching juga menunjukkan hasil bahwa model ini dapat meningkatkan hasil belajar siswa kelas IV SDN Sentul II Purwodadi Pasuruan. Pada siklus I, diperoleh hasil bahwa persentase ketuntasan belajar mencapai 55\% dengan nilai rata-rata 61. Persentase ketuntasan belajar secara klasikal meningkat sebesar $15 \%$ dari persentase sebelum tindakan. Nilai rata-rata juga mengalami peningkatan dari 56 menjadi 61 pada siklus II persentase ketuntasan belajar siswa secara klasikal juga mengalami peningkatan. Ketuntasan hasil belajar secara klasikal setelah diberi tindakan siklus II mencapai 80\% dimana presentase ini meningkat tinggi sebesar $25 \%$ dari siklus I. Rata-rata yang didapatkan pada siklus II mencapai angka 73 lebih tinggi daripada rata-rata siklus I.

\section{Daftar Rujukan}

Akbar, S. (2013). Penelitian Tindakan Kelas. Yogyakarta: Cipta Media.

Ali, H. G. (2013). Prinsip-Prinsip Pembelajaran dan Implikasinya Terhadap Pendidik dan Peserta Didik. Jurnal Al-Ta'dib, 6(1), 31-42.

Bujuri, D. A. (2018). Analisis Perkembangan Kognitif Anak Usia Dasar. Jurnal Literasi, 9(1), 37-50.

De Porter, B., Reardon, M., \& Nourie, S. S. (2013). Quantum Teaching Mempraktikkan Quantum Learning di Ruang-Ruang Kelas. Bandung: Mizan Media Utama.

Kemmis, S., McTaggart, R., \& Nixon, R. (2014). The Action Research Planner Doing Critical Participatory Action Research. London: Springer. 
Mulia, D.S. \& Suwarno. (2016). PTK (Penelitian Tindakan Kelas) dengan Pembelajaran Berbasis Kearifan Lokal dan Penulisan Artikel Ilmiah di SD Negeri Kalisube Banyumas. Jurnal Ilmiah Kependidikan, 9(2), 1-11.

Nurfirdaus, N. \& Hodijah, N. (2018). Studi Tentang Peran Lingkungan Sekolah dan Pembentukan Perilaku Sosial Siswa SDN 3 Cisantana. Jurnal Ilmiah Educator, 4(2), 113-129.

Santrock, J. W. (2014). Psikologi Pendidikan. Jakarta: Salemba Humanika.

Setyosari, P. (2014). Menciptakan Pembelajaran yang Efektif dan Berkualitas. Jurnal Inovasi dan Teknologi Pembelajaran, 1(1), 20-30.

Sugiyarti, L., Arif, A., \& Mursalin. (2018). Pembelajaran Abad 21 di SD. Jurnal disajikan dalam Prosiding Seminar dan Diskusi Nasional Pendidikan Dasar, Universitas Negeri Jakarta, Jakarta, 31 Januari.

Susanti, S. \& Miaz, Y. (2020). Peningkatan Hasil Belajar Siswa pada Tematik Terpadu dengan Menggunakan Model Quantum Teaching di Sekolah Dasar. Jurnal Inovasi Pembelajaran SD, 8(9), 22-30.

Tambunan, R. (2018). Penerapan Model Pembelajaran Quantum Teaching untuk Meningkatkan Hasil Belajar IPA Siswa Kelas VI A SDN 011 Bukit Gajah Kecamatan Ukui. Jurnal Primary, 5(3), 341-360. 